\title{
STRATEGIES FOR THE FIGHT AGAINST FEMALE GENITAL MUTILATION IN EUROPE ${ }^{1}$
}

\author{
Nieves Sanz Mulas*
}

\begin{abstract}
European countries face the challenge of multiculturalism and they are at loggerheads with practices such as FGM, where conflict arises between respect for the values upheld within a given culture and the criminal laws of the host country. In the present contribution, the author attempts to unravel the problem of whether this practice, despite the repugnance that it evokes in us, should be subject to a special kind of criminal treatment owing to its inescapable cultural basis (cultural defence). In any case, if customs such as FGM are to be eradicated a schema beyond current criminal law is needed; it would be necessary to adopt a global approach that places these customs and traditions within the context of violence and discrimination against women in different cultures. It is with respect to women that, religious and community prescriptions often result in forms of oppression and discrimination, and this is something that, far from diminishing, is actually being reinforced by the phenomenon of migration itself. Thus, the conditions that host societies make available to immigrants are crucial, and a greater equality of rights, with equal consideration and respect by the public authorities, carries with it greater possibilities of integration and the prevention of culturally motivated crimes. Without equality, dialogue is not possible, but the truth of the matter is that, the asymmetry between interlocutors is increasing with the same intensity as underdevelopment, unemployment and disparities in wealth.
\end{abstract}

INTRODUCTION

A. Culture and Multiculturalism .......................................... 899

B. Is European Society a Multicultural Society? ......................... 900

I. Multiculturalism and Criminal Law: Culturally Motivated Crimes (Cultural OfFEnces) AND Human Rights AS AN

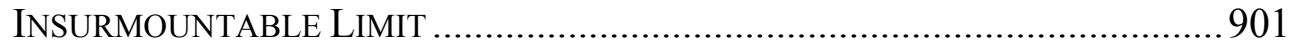

II. FGM AND EUROPEAN CRIMINAL POLICY ..........................................903

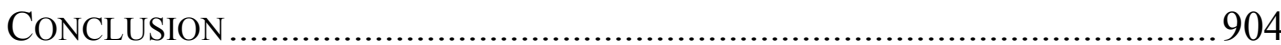

\footnotetext{
${ }^{1}$ This paper is published as part of the project "Criminal policy against Transnational Crime" (http://crimen.eu/en/research-projects). Funding Body: Ministerio de Economía y Competitividad del Gobierno de España (Ministry of Economy and Competitiveness - Government of Spain). Reference: DER2012-31368.

${ }^{*} \mathrm{PhD}$ in Criminal Law. Senior Lecturer Department of Criminal Law at the School of Law, and Director of Gender Equality Unit of University of Salamanca, Spain. Research fields: Criminal Law, Criminal Policy, Prison Law, Gender Violence and Equality, Juvenile Delinquency (http://crimen.eu/en/about-us?id=24).
} 


\section{INTRODUCTION}

\section{A. Culture and Multiculturalism}

Among other novelties, globalization has introduced us to a world of diversity and change as well as a greater awareness of people's own ethnic and cultural roots. Although the multifocal and confusing world that emerged after the Cold War is today the scenario of many, usually bloody, national and tribal conflicts, there is no doubt that, the greatest threats to stability stem from conflicts between States or groups from different civilizations. The homogeneity of globalization contrasts with the appraisal of the autonomy and peculiarities of minorities, and currently, we are inexorably bound to facing the challenge of multiculturalism. Tied in with this is a challenge for criminal law, which has traditionally been constructed around the values of a society considered (wrongly) to be homogeneous, a perspective that according to the evidence from a large majority of multicultural States is no longer tenable. We are thus witnessing an unquestionable reality that affects some the basic principles of States, such as legality and culpability, and one that even requires a reformulation of their own categories to adapt them to the new requirements.

Although the phenomenon of migration is as old has humanity itself, the current difference is the amplitude and the regularity that it has acquired in vast regions of the planet, indeed reaching global proportions. Thus, the underlying fabric of everyday life has been altered and now reflects an unprecedented degree of diversity. The second half of the twentieth century saw the most rapid, profound and universal transformations of human history $^{2}$ and in societies such as those prevailing in Europe, for example, this has created a melting-pot of civilizations where strikingly different ethnicities, cultures, customs, religious practices and traditions struggle to coexist. In light of this, in our Old World, we may now speak of a "nomadic civilization", formed by modern multi-ethnic, multicultural and multireligious societies. However, this is also a potential source of conflicts, agreements and disagreements, with a clearly ethnocentric starting point; that is, it is based on the emotional tendency to take one's own culture as an exclusive criterion, to interpret the behaviour of other groups, ethnicities or societies. This is because the meeting of cultures usually involves direct confrontation rather than distant recognition, because each culture is a coherent whole, distinct from others, and it protects itself from them ${ }^{3}$.

\footnotetext{
${ }^{2}$ E. J. Hobsbawn, Identity, InTERnational Journal of Political Philosophy 3 (1994).

${ }^{3}$ A. TOURAINE, Can We Live Together?, EQUALS AND DifFERENT (Madrid: PPC 1997).
} 
Multiculturalism is therefore configured as an ideal of the coexistence of a pluralist society and fellowship characterized and enriched by the differences in each group. In other words, we are dealing with a management model of multiculturality in a democratic society interested in defending the vulnerability of minority cultures by promoting the exercise of cultural diversity and condemning intolerance. This is so because globalization is now threatening a sacrosanct element for human beings, i.e., belonging to a well-defined group, and this affects their welfare and personal identity, and endangers their right to religion, language and culture ${ }^{4}$. In short, it is about learning to live in a society that will permit peaceful interchange, the possibility of different cultures learning from each other, and mutual respect for their stories, ideals, arts and cultural underpinnings.

\section{B. Is European Society a Multicultural Society?}

The answer to this must be no. In host countries, the absence of European Community policies for the social cohesion and cultural integration of immigrants is conspicuous, this despite the EC having based its intervention, for more than two decades now, on a tripartite axis ${ }^{5}$ : the control of migration flows (definitely the central axis of EU policies on immigration), the integration of immigrants, and cooperation for development. Further, in this period of crisis and globalisation, the immigration issue and its use by politicians and the media have led the acquisition of nationality and citizenship to become major problems in national policies.

To begin with, foreigners are subject to significant limitations and restrictions in matters such as the issuance of residency permits, which immediately converts them into "partial citizens" since it limits their rights to freedom of movement, political participation, education, employment and social security benefits, health care, access to justice and family reunification. It could therefore be suggested that, Europe has by no means adopted a multicultural approach to immigrant minorities. In European society, immigrants still generate distrust, and there are many stereotypes and prejudices that, exploited by political leaders themselves, justify the adoption of clearly racist and xenophobic measures. In short, in Europe coexistence with immigrants, although peaceful, still struggles under an

\footnotetext{
${ }^{4}$ O. HöfFe, InTercultural Law (Barcelona: Gedisa 2000).

${ }^{5}$ F. Sanabria, Immigration and Culture: Coexistence, Integration, Assimilation, CUADERNOS DE Pensamiento Político (October/December 2006).
} 
umbrella of separation and distance. Our Old World clings to restrictive immigration policies, based on the closing of borders, the denial of civil and political rights, the rejection of positive discrimination policies for immigrants, the restriction of residency and citizenship for newcomers, and expulsion or "voluntary" return, especially in the case groups of unwanted immigrants considered to be "non-integrable".

\section{Multiculturalism AND CRiminal Law: Culturally Motivated CRimes (Cultural OFFENCES) AND HuMAN RightS AS AN INSURMOUNTABLE LIMIT}

Multiculturalism therefore also entails problems that States must face, even through criminal law. Diversity should also be protected by criminal law from possible excesses and attacks; that is, it is necessary to set limits to tolerance. Tolerance is elasticity with limits, but where can we set the border that will allow us to speak about culturally motivated crimes (cultural offences) and find, if possible, specific responses? That is, in the words of Carnevali ${ }^{6}$, we must ask whether it is valid or not to maintain a kind of presumption of equality between the values of different cultures or, if appropriate, that a society should pass a judgment of legitimacy regarding the behaviour of other minority cultures.

Regarding culturally motivated crimes, with this we understand cases in which certain types of behaviour contrary to the criminal norms of the "host" country are explained in terms of the culture to which the offender belongs; that is, the behaviour is carried out by someone who belongs to a minority culture in which such behaviour is not considered criminal. It may also be the case that, such behaviour is deemed criminal in both cultures, but the punishment met out is different. In short, we are dealing here with a conflict between respect for the values upheld within the immigrant's culture and what the criminal laws of the host country provide for. Cultural offence therefore arises from one perception of culture, but is repressed by a different one. This being so, how can we demand obedience and loyalty to certain values encompassed within a legal system foreign to the immigrant, who may even be unaware of the strictures of the laws of the host country? If in any case, it is decided to apply the legislation of the host country, are the existing resources in the theory of crime sufficient, or it is necessary to reinvent the categories that have to date been used by the criminal doctrine? In sum, what should the criminal law that is already facing this "new" social

\footnotetext{
${ }^{6}$ R. Carnevali, Multiculturalism: A Challenge for the Modern Criminal Law, 3(A6) Politica Criminal (2007).
} 
reality be like? Should it be a purely western criminal law?

Certainly, the answer is not simple. Neither legal isolation, as uncompromising defence of the cultural norms of ethnic minorities, nor homogeneous integration bordering on assimilationism, seems to provide an adequate response to cultural plurality and diversity. The inadequacy of traditional criminal law for dealing with cultural offences is certainly evident, but even then, should it actually be implemented? It is suggested that, the answer to this is yes; it is necessary to establish a minimum common denominator in criminal policies because, in complete agreement with Vazquez $^{7}$, not every difference or diversity is ethically acceptable, and neither all cultural points of view have, in themselves, the same ethical value. We shall not advance in the direction of resolving these issues if on the basis of a poorly understood pluralism, we continue to allow the presence of cultures featuring repeated abuses of individual rights to flourish (e.g., FGM).

The minimum common denominator in the whole issue is respect for human rights: the right of every human being to have rights. According to Benhabib $^{8}$, this means to be recognized by others and to recognize others as persons worthy of moral respect and the rights guaranteed by the law within a human community. Thus, restricting certain cultural expressions would be justified, since there are minimum boundaries that no society can renounce and that are based on fundamental rights, universal and inalienable rights that cannot be invalidated by cultural consensus of any kind.

However, no should we ignore the potential risk of "Occidentalism" because there are already countless examples of human rights violations and manifestations of the criminal law of the enemy in State legislations with a consolidated enlightened tradition, such as in Europe. We must therefore free human rights from the interventionist rhetoric that so often accompanies them. That is, we must escape from a blind and pretentious "Occidentalism", that is limited to thinking that, such reprehensible types of behaviour are merely manifestations of new barbarities that will finally vanish naturally under the "democratic boot" of a civilized society.

In any case, it does not suffice simply to talk about human rights, or automatically assume them as our basic legitimizing rationale. Before this, we must ensure that, they will be respected in the "assumed paradise" of western civilization. The recognition of human rights makes no sense without prior public defence against attacks on them, which presupposes the

\footnotetext{
${ }^{7}$ C. Vázquez, Inmigration, Diversity and Cultural Conflict, (Madrid: Dykinson 2010).

${ }^{8}$ S. Benhabid, Another Universalism: On the Unity and Diversity of Human Rights, 81(2) Proceedings and Addresses of the American Philosophical Association (2007).
} 
acceptance of human sociability, coexistence, and a minimal social organization within which such defence can be exercised. That is, the reality of human rights should never be separated from sociability, from coexistence as a personal trait, and the principle of safety in social life associated with it.

\section{FGM AND EUROPEAN CRIMINAL POLICY}

According to the definition of Amnesty International (1998) ${ }^{9}$, female genital mutilation (FGM) is the term used to refer to the partial or total removal of the female genital organs on cultural or religious grounds or for other non-therapeutic reasons. Ablation, also known as female circumcision, causes permanent and irreversible health problems, and although it is mainly practised in Africa and some Middle Eastern countries, Europe is not exempt. According to the WHO, about 140 million and girls currently suffer the consequences of genital mutilation, and two million girls and adolescents are subjected to it each year. In Africa, it is carried out widely, and it is common practice in some countries of the Middle East. It also occurs in parts of Asia and the Pacific, North America, Latin America and Europe. In industrialized countries, FGM is performed mostly among immigrants from the countries where it is practiced. In this regard, there are reports of mutilations in Australia, Canada, Denmark, USA, France, Italy, Norway, Netherlands, the UK and Sweden. In Europe, around 500,000 women and girls have been victims of FGM and 180,000 are at risk of being subjected to it. Specifically, according to data from a study by the University of Barcelona ${ }^{10}$, in 2012, it was estimated that, Spain had about 17,000 children at risk of suffering ablation.

In Europe, the solutions adopted to eradicate FGM are varied: Some countries have enacted ad hoc criminal laws to prohibit and criminalize its practice (countries such as the UK and Sweden); others have reformed their criminal codes by including it as a specific crime (among other countries, Belgium, Denmark and Italy), while others have chosen not to categorize it expressly, since they consider that, there are already offenses within which this practise can be encompassed perfectly, mainly crimes of injury and their possible aggravated types when the victims are minors or the injuries are committed by their parents or guardians (Germany, Finland, France, Greece,

\footnotetext{
${ }^{9}$ International Amnesty, Female Genital Mutilation and Human Rights, (Madrid: Amnistía Internacional 1998).

${ }^{10}$ Kaplan \& López, Map of Female Genital Mutilation in Spain, (Barcelona: Fundación WassuUniversidad Autónoma de Barcelona 2012).
} 
Holland, Ireland, Luxembourg, Portugal, Spain, etc.). This latter option, despite being the majority, however, is problematic. On one hand, this may lead judges to apply an attenuated form of injury, with too lenient a sentence, to incomplete or no definitive mutilations, while on the other, when the FGM in considered within the most serious types of injuries and is committed against minors, they parents are punished with an excessively heavy punishment ${ }^{11}$.

In any case, what is most worrying is that, none of the European legal systems has attempted to incorporate, to one degree or another, cultural specificity in the area of criminal law. Despite the pompous declarations of intention, not only is cultural diversity not recognized when it conflicts with the prevailing norms, but even when it is recognised, it is pursued with all means available (zero tolerance). And this without considering that, the social construction of otherness as barbaric or uncivilized, is not a good starting point to promote either intercultural dialogue or social change because it is limited to stigmatize ${ }^{12}$.

\section{CONCLUSION}

From the above, it is clear that, European legislators cannot remain insensitive to these signs of our time and, unless they wish to be overtaken by history, they must face up to the problem of cultural conflicts in a reasoned way. Cultural pluralism is here to stay, and a new social order can only be achieved by protecting and respecting cultural diversity, because the future of our societies depends on it more than ever before ${ }^{13}$. Faced with this reality, repression through the criminal law is no more than a partial solution, a "patch". The problem of FGM, like the Islamic veil and many other manifestations, goes far beyond the "nuisance" inherent to any crime: these manifestations reveal the new tensions and conflicts of the multicultural societies of our times, the confrontation of religion and cultural values with post-modern values.

Sometimes, immigrants tend to strengthen their practices and traditions, and may even become more religious or traditional in the host nation than they were in their home country. Accordingly, the conditions that host societies make available for immigrants are crucial, and greater equality of rights, with equal consideration and respect by the public authorities, offers

\footnotetext{
${ }^{11}$ C. Vázquez, Immigration, Diversity and Cultural Conflict, (Madrid: Dykinson 2010).

${ }^{12}$ M. J. Guerra, Cultures and Gender: Harmful Practices, Feminist Interventions and Women'S Rights, Isegoría. Revista de Filosofía Moral y Política 38 (2008).

${ }^{13}$ M. Foblets, Cultural Crimes: The Impact of Cultural Conflicts on Criminal Behavior, ANUARIO DE DERECHO PENAL (2006).
} 
greater possibilities of integration and the prevention of culturally motivated crimes $^{14}$. Without equality dialogue is not possible, but the reality is that, the asymmetry between interlocutors grows with the same intensity as underdevelopment, unemployment and differences in wealth. It would be ingenuous to cast doubt on the patriarchal nature of different cultures -our own western culture and others - and the uneven impact of processes of enlightenment, of social reflection, bound to the universal values of equality, freedom and justice.

In any case, although no culture can purport to be the carrier of absolute truths, tradition should not be identified with the perpetuation of marginalization, backwardness and obscurity. We can now go beyond western arrogance and superiority and propose that, neither human rights nor democracy are specifically European or western phenomena ${ }^{15}$. However, there can be no democracy without the institutional protection of personal and collective freedom, because today democracy offers the alternative of expanding state legitimacy and its power as regards personal freedom and people's human, cultural, individual and collective rights, preventing discrimination and respecting different ways of reasoning ${ }^{16}$. All this because, ultimately, no sensible person would consciously choose be eternally foreign.

Thus, the desire to live in Europe is irreconcilable with a radical rejection of it. In this sense, the integration capacity of immigration and its cultural diversity depends mainly on the tolerance or intolerance of our own culture. This is because the linguistic, ethnic and cultural mosaic that has become Europe, as claimed by Muñoz ${ }^{17}$, is a multiverse that, invites us to learn from the differences and not only to respect them; it is a school of positive and active tolerance, not merely passive, like the superior who "spares the life" of his inferiors. And it is also a school of creativity, of "justice". Accordingly, we must look to the "other" without prejudice; we must consider how we would feel inside their body, look through their eyes and learn from their experiences, because, albeit with different moulds, we are all made of the same mud. The human being is always wonderful, and how and where we are born, live or die is, in the long run, a matter of "luck".

\footnotetext{
14 Mestre I. Mestre \& García Añón, Female Genital Mutilations. Available at http://www.tiempodelosderechos.es/docs/feb12/mutilaciones.pdf.

${ }^{15}$ O. HöFFe, InTERCULTURAL LAW (Barcelona: Gedisa 2000).

${ }^{16}$ E. Aguilar, Revista Multidisciplina. Revista Electrónica de la Facultad de Estudios Superiores de Acatlán, II(4) Multiculturalism AND LAW (2009).

${ }^{17}$ J. Muñoz, Dialogue and Conflict between Civilations, Claves de Razón PráctiCa 179 (2008).
} 